\title{
Accounting Implications of Micro-Fiscal Measures and Quality of Real Gross National Goods and Services: Empirical Evidence From Nigeria
}

\author{
Akabom I. Asuquo ${ }^{1}$, Arzizeh Tiesieh Tapang ${ }^{2}$, Uwem E. Uwah ${ }^{3}$, Nicholas O. Dan ${ }^{1} \&$ Ashishie Peter Uklala ${ }^{1}$ \\ ${ }^{1}$ Department of Accounting, University of Calabar, Calabar, Nigeria \\ ${ }^{2}$ Department of Accounting, College of Management Sciences, Michael Okpara University of Agriculture Umunike, \\ Umuahia, Nigeria \\ ${ }^{3}$ Department of Accounting, Akwa Ibom State University, Nigeria \\ Correspondence: Akabom I. Asuquo, Associate Professor, Department of Accounting, University of Calabar, Calabar, \\ Cross River State, Nigeria. E-mail: drakabom3@gmail.com
}

Received: July 24, 2020

doi:10.5430/rwe.v11n6p155
Accepted: September 24, 2020

Online Published: October 8, 2020

URL: https://doi.org/10.5430/rwe.v11n6p155

\begin{abstract}
The study explored into accounting implications of micro-fiscal measures and quality of real gross national goods and services: empirical evidence from Nigeria for a period of thirty years. The objective was to examine how micro-fiscal measures affect real gross national goods and services using thirty years' time-series data. The exploratory research methodology was applied and data collected were analysed using multiple regression and other statistical techniques. Findings of the study revealed that significant and direct effects were exerted on gross national goods and services by all the known and identified micro-fiscal measures in the review, except swap and levy ratios which had inverse relationship as revealed by their coefficients obtained from the analysis. Therefore, the government and government agencies have a duty to control macro-fiscal activities in terms of creation of national goods, wealth and services using the identified micro-fiscal mechanisms as the basis for decisions and policies making besides implementation.
\end{abstract}

Keywords: accounting implications, goods, gross, micro-fiscal measures, quality, real

\section{Introduction}

National income accounting which leads to the estimation of the magnitude and quality of all real and material gross national goods and services generated in an economy in given periods or particular years is paramount for every nation. It enables the ruling government to determine the quantum or magnitudes of real goods or services produced within the economy in a fiscal year. In trying to undertake estimate, certain macro-fiscal indicators are taken into serious consideration to ensure proper and accurate estimation. These micro-fiscal gauges as identified and used in the review are charges ratio; price raises ratio, external swap ratio, levy ratio, as well as purchaser charge catalogue. This charges ratio here is operationally defined as the investment's earning ability or the ratio at which government issues or sale bonds/investments in a particular fiscal year, The price rises ratio is the extent to which the amount of money in circulation is more than the number of merchandises as well as amenities which are available within the frugality to meet the demand by the citizens. The swap ratio is the magnitude by the side of which the national legal tender is swapped for overseas monies. Levy ratio is a charge on the levy base, which is the amount of levy that is taken from the chargeable base as a compulsory payment/levy to the national government. The purchaser charge catalogue is defined as the aggregate charge level and the market value in this study.

Anyanwu (1993; 1995), Asuquo (2012a), Asuquo and Effiong (2011) jointly emphasized that it is worthy to note that the national government uses the above enumerated micro-fiscal measures otherwise known as micro-economic variables control the economy in order to achieve the set macro-economic goals. Which are: Price stability, redistribution of income from the high to low-income earners, reduction of unemployment level, maintaining law and order, political stability, balance of trade, provision of social infrastructures within the economy and other heavy-weight responsibilities which could be done by the citizens and private organizations? Okonkwo (2015) and Vincent (2018) were of the opinion that economic development is been one of the key macro-economic goals of every nation, from self-determination without exterior philosophy till using fiscal and monetary policies. In order to 
accomplish these objectives, the government needs to develop the real sector of the economy in order to produce sufficient real gross national goods that meet the needs of the domestic economy.

\section{Literature Reviews}

\subsection{Evaluation of Income and Productivity Towards the Creation of Gross National Goods and Services}

Asechemie (1999) and Victor (2019) averred that recurrently, the fundamentals for the quantification of productivity in the secretive segment, over a specified historical of time are the earnings amount. Nevertheless, such pointers of productivity are not obtainable in the communal subdivision since the subdivision only embarks on benefit-driven undertakings. In addition, government undertakings are embarked on to impact and encourage general public as well as systematized and structured articulating packages, strategies in addition to guidelines. The assessment of the productivity and administrative schemes emphasise course of actions and linked expenditures which consequently determine the quantum of real gross national goods that have been created in a particular year. As submitted by Abdulahi (2015), Abdulahi, Aliero and Abdulahi (2012), and Asechemie (1999), the main contending issues, nevertheless, arise from the evaluation of plan effects, strategies and productivity determination in relation to gross national item for consumption and services. In spite of the complications connected with productivity appraisal in the general segment, the benefits of productivity evaluation ought not to be bargain (Asuquo, 2012a). As also averred by Asuquo and Effiong, (2010) citizens are developed, trained, built and encouraged in the direction of national production and creation of magnitude and quality of real gross goods and services, and also with respect the amount revenue generated towards facilitating economic recovery and development without wasting or misappropriating scarce resources.

\subsection{Government Finance and Revenue Base Towards National Income Accounting}

Adams (2001) and Abraham "unpublished" (2019) in stressing the basic need for government to generation revenues up to the level that is enough to carry out its statutory functions argued in favour of the government by pointing out the need for government to assess and impose levy on the citizenry. Adejumo and Adejumo (2014), Ayejide "unpublished"' (2018), Ezeani (2004), and Williamson (2019) asserted that the capability of the government to recognize and preserve feasible and viable income bases is an imperative benchmark and target in evaluating the effectiveness and efficiency with which its purposes and goals are accomplished in the direction of maintainable development, growth and economic stability. Similarly, Wilson "unpublished" (2019) and Willey "unpublished" (2019) explained that accountability, answerability and transparency for national wealth and competence facilities rationalized the presence of the nation and her administrators. Jhinga (2010) and Wilcox "unpublished" (2018) noted that the central or national government is the focal point of a nation and must be capable of enforcing and maintaining laws and order towards economic and political stability. Consequently, its fiscal and monetary policies will all aim at providing a thriving economic environment that will in turn enhance productivity as argued by both Asuquo (2012a), and Wuse (2018).

\subsection{Swap Ratio Risk Exposure and Charges Ratio Instability}

Asuquo (2012a, 2012b), Jorion (1990), Luehrman (1991), Zubeiru and Adjasi (2007) asserted that inconsistency in the interchange or ratio is a key foundation of macro-fiscal improbability upsetting firms and the economic activities in general. Luehrman (1991), Zuberiru and Adjasi (2007) explained that swapping ratio upsurge and intensification weaken the desirability and pull for carry across or overseas trading which in the long run generate adverse impact and undesirable consequences for the interior and core dealings. On the other hand, the nation states which are characterized by rapid upswing and instability in the swap ratio often face with adverse balance of trade. Therefore, proliferation of wealth and asset creation by domestic company as a result of material dwindling in the domestic legal tender could materially reduce formation and creating of real gross national goods and services. Udoayang, Akpanuko and Asuquo (2009) were also aligned to the fact that intercontinental and exterior dealings lead to the need to negotiate and agree on the swapping ratios or charges by trading parties.

\subsection{Current Value and Distortion of Accounting Data During the Inflationary Period}

Asuquo (2012a; 2012b) and Jorion (1990) averred that the economic activities of a firm are recorded by an accounting and management information system that applies for money as the common scale of measuring all the activities. As the scale of measurement changes, a traditional book-keeping report (grounded on the past cost determination) distorts figures. Profit and loss accounts, balance sheets, budgets, standard costs, and prices are all distorted and cannot be used correctly to manage a firm. As soon as facts are distorted, management activities may be misleading as well. The change in procuring capability of money can cause considerable misrepresentations in the financial reports during a period of inflation. They further asserted that an orthodox business account reveals trades in the relation of the number 
of components of currency swapped and this in turn affects value of real goods or services produced within the economy. Nevertheless, they reported that chronological cost reports normally quantify interchange prices at the business period and overlook variations in worth up to one more business taking place. By means of the noteworthy value variations taking place over the previous years, there has been increasing anxiety around the practicality of historic cost reports and the value of national goods manufactured.

\section{Materials and Methodology}

\subsection{Research Designs and Source of Data}

This study adopted the exploratory methodology. This choice was informed by the fact that the variables of the study were not manipulated and controlled and there was a need to determine the effect of one variable on another. In other words, the designs were suitable for the research because it is not possible to directly manipulate or control any of the independent variables. This is because the event had already taken place hence the research was carried out after the facts had occurred. It was well-thought-out most suitable for this research because the study required the use of secondary facts gathered from Numerical Communiqués (Central Bank of Nigeria [CBN], 2000, 2003, and 2005), Bureau of Indicators documentation and Index Mundi (2012), reports and extracts for a period of thirty years.

\subsection{Prototypical Arrangement}

$$
\begin{gathered}
\text { RGNGS }=\mathrm{F}(\mathrm{MFM}) \\
\text { RGNGS }=\mathrm{a}_{0}+\mathrm{b}_{1} \mathrm{CR}_{\mathrm{i}-\mathrm{t}}+\mathrm{b}_{2} \mathrm{PRR}_{\mathrm{i}-\mathrm{t}}+\mathrm{b}_{3} \mathrm{SR}_{\mathrm{i}-\mathrm{t}}+\mathrm{b}_{4} \mathrm{LR}_{\mathrm{i}-\mathrm{t}}+\mathrm{b}_{5} \mathrm{PCC}_{\mathrm{i}-\mathrm{t}}+\mathrm{Err}
\end{gathered}
$$

The above model is further expressed in five functional forms which were tried in order to indicate the prime equivalence for each position.

These are:

1. Linear

2. Exponential

$$
\text { - } R G N G S=b_{o}+b_{1} C R+b_{2} P R R+b_{3} S R+b_{4} L R+b_{5} P C C+e_{1}
$$

3. Semi logarithmic $\quad-\ln R G N G S=\ln b_{o}+b_{1} \ln C R+b_{2} \ln P R R+b_{3} \ln S R+b_{4} \ln L R+b_{5} \ln P C C+e_{1}$

4. Double logarithmic $\ln R G N G S=\ln b_{o}+\ln b_{1} C R+\ln b_{2} P R R+\ln b_{3} S R+\ln b_{4} L R+\ln b_{5} P C C+e_{1}$

5. Triple logarithmic $\quad-\ln R G N G S=\ln b_{o}+\ln b_{1} C R+\ln b_{2} P R R+\ln b_{3} S R+\ln b_{4} L R+\ln b_{5} P C C+e_{1}$

Where the Real Gross National Goods and Services [RGNGS], dependent variables, Micro-fiscal measures [MFM], independent variables, and are represented by Charges ratio [CR], Price rises ratio [PRR], Swap ratio [SR], Levy ratio [LR], Purchaser charges Catalogue [PCC]. Then Err stands for the error terms, which are the difference between the estimated value of RGNGS using the independent variables and the actual or given value of the dependent variable. ' $\mathrm{a}_{0}$ represents constant term, which is the coefficient of other factors not mentioned in the model or that are held constant, which have jointly influence the estimated worth of the reliant adaptable given the respective values of the independent variables. $b_{2}, b 2, b_{3}, b_{4}, \& b 5$ are the regression coefficients of CR, PRR, SR, LR, and PCC respectively. I in period $t ; t=$ Times series measurement (Series from 1 to $t$; 1989-2019).

\subsection{Method of Data Analysis}

Data were presented on tables and later analysed using the multiple regression method. All propositions were tested using the panel regression analysis. The correlation coefficient (r) was used to show if there is a relationship between the data. $R^{2}$ (Coefficient of determination) established the influence of the self-determining adjustable (CR, PRR, SR, LR, PCC) on the total deviation of the dependent variable (RGNGS). The statistical significance of the result was determined using the $\mathrm{P}$ values of $\mathrm{t}$ - statistics and $\mathrm{F}$ - statistics at a five per cent level of significance. The worthless hypotheses were to be recognized if the t-worth was less than two at a 95 per cent self-confidence level, otherwise, they were rejected and the alternatives $\left(\mathrm{H}_{1}\right)$ accepted. Results presented in Table 2 led to the rejection of all the null hypotheses as to their respective $t$-worth were greater than two.

\section{Results}

\subsection{Results Presentation}

Table 1. Thirty years' time series data analysis: dependent variable (RGNGS), independent variables $(\mathrm{MFM})=\mathrm{CR}$, PRR, SR, LR \& PCC

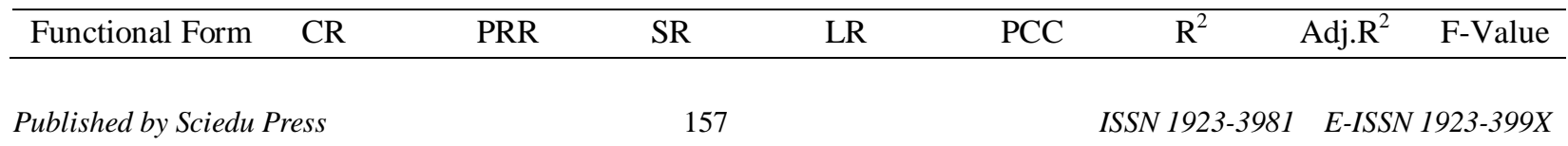




\begin{tabular}{lllllllll}
\hline Linear & 0.0067 & $1.2341^{*}$ & -1.3030 & -2.3040 & $1.2321^{*}$ & $0.89^{*}$ & 0.79 & $64.25^{*}$ \\
& $(0.2004)$ & $(1.2320)$ & $(1.2200)$ & $(0.3060)$ & $(1.2310)$ & & & \\
\hline Semi Log & $1.14341^{*}$ & $0.0001^{*}$ & -1.4020 & $1.3422^{*}$ & 0.0010 & $0.86^{*}$ & 0.78 & $62.95^{*}$ \\
& $(2.3222)$ & $(2.1232)$ & $(1.4010)$ & $(2.4011)$ & $(2.211)$ & & & \\
\hline Double Log & $1.2480^{*}$ & -0.1510 & $0.1000^{*}$ & -1.5640 & -0.1510 & $0.89^{*}$ & 0.78 & $64.95^{*}$ \\
& $(0.3150)$ & $(0.3300)$ & $(0.4600)$ & $(0.8430)$ & $(0.3300)$ & & & \\
\hline Exponential & $0.0003^{*}$ & $0.0004^{*}$ & 0.0004 & $0.0004^{*}$ & 0.0003 & $0.87^{*}$ & 0.85 & $0.75^{*}$ \\
& $(0.0002)$ & $(0.0001)$ & $(0.0001)$ & $(0.00001)$ & $(0.0000)$ & & & \\
\hline
\end{tabular}

Durbin Watson Statistics $=4.23 * \quad *$ Significant at 5 per cent level.

Source: Analysis by the Authors

Table 2. Regression results on dependent variable (RGNGS); Independent variables $(M F M)=C R, P R R, S R, L R \&$ PCC

(30 years' time series data)

\begin{tabular}{llll}
\hline Variables & P-value & T-value & Significant level \\
\hline CR & 0.00132 & 3.2340 & Significant. \\
\hline PRR & 0.00142 & 4.0230 & Significant. \\
\hline SR & 0.00014 & 3.1284 & Significant. \\
\hline LR & 0.00030 & 2.5346 & Significant. \\
\hline PCC & 0.00003 & 4.1220 & Significant. \\
\hline
\end{tabular}

Source: Analysis by Researchers

\subsection{Discussion of Findings}

The results of the multiple regression analysis of the micro-fiscal measures on magnitude and quality of real gross national goods and services presented in Table 1 above, indicating the parameters estimated from the data gathered for the study. An $\mathrm{R}^{2}$ of 0.89 indicates 89 per cent changeability and variability in the magnitude and quality of real gross national goods and services is explained by the independent variables (micro-fiscal measures) contained within the model. In addition, the F-worth as 64.25 has revealed that the model was significant at a 5 per cent level which also implies that the regression model has an explanatory ability. The coefficient of multiple determinations $\left(\mathrm{R}^{2}\right)$ predicts the combined effects of the independent variables which are denoted as CR, PRR, SR, LR, and PCC respectively (see 3.2: model specification). Consequently, CR, PRR, SR LR and PCC are equally significant at the 5 per cent level since the model is significant. 89 per cent and the explanation of variation in quality and quantity of RGNGS is provided by changes in CR, PRR, SR, LR, and PCC respectively. This combined prediction of RGNGS, the dependent variable is great. The significance of the model was tested and F-worth of 64.25 was possible at a 5 per cent level of significance. Also, the Durbin Watson Statistics (DW) of 4.23 as shown in table 1 pronounced that there no auto-correlation amongst the independent variables, implying each independent variable of the study was competent to explain variation in the dependent variables without interference. The following results were also revealed concerning the null hypotheses formulated for the study:

\section{Hypothesis one:}

$\mathrm{H}_{\mathrm{o}}$ : Charges ratio does not materially affect the magnitude and quality of real gross national goods and services.

$\mathrm{H}_{1}$ : Charges ratio materially affects the magnitude and quality of real gross national goods and services.

From the regression result, the T-worth for CR (3.2340) in table 2 is greater than 2.00, consequently, charges ratio materially affects the magnitude and quality of real gross national goods and services for the period under assessment.

\section{Hypothesis two:}

$\mathrm{H}_{\mathrm{o}}$ : Magnitude and quality of real gross national goods and services are not considerably impacted by price rises ratio.

$\mathrm{H}_{1}$ : Magnitude and quality of real gross national goods and services are considerably impacted by price rises ratio

For hypothesis two, the T- value for PRR (4.0230) in table 2 is greater than 2.00, there based useful benchmark, it inferred that magnitude and quality of real gross national goods and services are considerably impacted by price rises 
ratio for the period under evaluation. This result is in agreement with the findings made by Asuquo (2012b), which interconnected and linked prices rise ratio to economic growth and development that invariable are greatly influenced by the magnitude and quality of real national goods and services that are produced in the economy in a given period.

\section{Hypothesis three:}

$\mathrm{H}_{\mathrm{o}}$ : Swap ratio substantially exerts no influence on the magnitude and quality of real gross national goods and services.

$\mathrm{H}_{1}$ : Swap ratio substantially exerts no influence on the magnitude and quality of real gross national goods and services.

For hypothesis three the T- value for SR (3.1284) in table 2 is greater than 2.00 implying that Swap ratio substantially exerts inverse influence on the real magnitude and quality of gross national goods and services in the period under review.

\section{Hypothesis four:}

$\mathrm{H}_{\mathrm{o}}$ : Levy ratio does not noticeably impact on the magnitude and quality of real gross national goods and services.

$\mathrm{H}_{1}$ : Levy ratio noticeably impacts on the magnitude and quality of real gross national goods and services.

For hypothesis four the T- value for LR (2.5346) in table 2 is greater than 2.00 and by implication levy ratio noticeably and inversely impacted on the quantity and quality of real gross national goods and services in the period under review.

\section{Hypothesis five:}

$\mathrm{H}_{\mathrm{o}}$ : Purchaser charge catalogue does not substantially affect the magnitude and quality of e real gross national goods and services.

$\mathrm{H}_{1}$ : Purchaser charge catalogue substantially affects the magnitude and quality of real gross national goods and services.

For hypothesis five the T-value for PCC (4.122) in Table 2 is greater than 2.00 which subsequently denote that purchaser charge catalogue substantially affects the magnitude and quality of real gross national goods and services in the period under exploration. It should be pointed out that the findings above are in agreement with the opinion and submissions made by Abraham (2019), Abdulahi, Aliero and Abdulahi (2012), Abdulahi (2015) and Asuquo (2012a).

Table 3. Computation of the trend, mean values and deviations of Micro-fiscal measures for 30 years range (1989-2019) extrapolated and draw conclusions values/quality

\begin{tabular}{llclllclclc}
\hline Years & CR\% Deviation & PRR\% & Deviation & SR\% & Deviation & Min. LR\% Deviation & PCC\% & Deviation \\
1 & 5.5 & - & 6.4 & - & 6.2 & - & 10 & 0 & 2.5 & - \\
2 & 5.5 & 0 & 8.1 & 1.7 & 8.3 & 2.1 & 10 & 0 & 3.5 & 1.0 \\
3 & 5.5 & 0 & 5.8 & -2.3 & 7.5 & -0.8 & 10 & 0 & 5.4 & 1.9 \\
4 & 4.3 & 1.2 & 6.4 & 0.6 & 5.2 & -2.3 & 10 & 0 & 6.4 & 1.0 \\
5 & 6.3 & 2.0 & 7.4 & 1.0 & 8.2 & 3.0 & 10 & 0 & 6.5 & 1.1 \\
6 & 6.5 & 0.2 & 5.4 & -2.0 & 6.2 & -2.0 & 10 & 0 & 4.5 & -2.0 \\
7 & 4.5 & -2.0 & 6.8 & 1.4 & 7.3 & 1.1 & 10 & 0 & 5.6 & 1.1 \\
8 & 5.5 & 1.0 & 4.8 & -2.0 & 9.5 & 2.2 & 10 & 0 & 7.4 & 1.8 \\
9 & 5.2 & -0.3 & 6.3 & 1.5 & 10.3 & 0.8 & 10 & 0 & 5.3 & -2.1 \\
10 & 6.5 & 1.3 & 5.4 & -0.9 & 10.2 & -0.1 & 10 & 0 & 6.1 & 0.8 \\
11 & 6.3 & -0.2 & 6.6 & 1.2 & 12.2 & 2.0 & 10 & 0 & 5.2 & -0.9 \\
12 & 5.4 & -0.9 & 7.7 & 1.1 & 10.4 & 1.8 & 10 & 0 & 6.5 & 1.3 \\
13 & 8.2 & 3.8 & 5.7 & -2.0 & 7.4 & -3.0 & 10 & 0 & 6.9 & 0.4 \\
14 & 5.5 & -2.7 & 6.2 & 0.5 & 8.3 & 0.9 & 10 & 0 & 5.6 & -1.3 \\
15 & 4.3 & -1.2 & 7.4 & 1.2 & 7.2 & -1.1 & 10 & 0 & 6.2 & 0.6 \\
16 & 4.3 & 0 & 8.4 & 1.0 & 7.2 & 0 & 7.5 & -2.5 & 7.3 & 1.1 \\
17 & 2.5 & -1.8 & 5.4 & -3.0 & 6.2 & -1.0 & 7.5 & 0 & 8.5 & 1.2 \\
18 & 3.5 & 1.0 & 6.8 & 1.4 & 7.3 & 1.1 & 7.5 & 0 & 6.2 & -2.3 \\
19 & 4.5 & 1.0 & 5.8 & -1.0 & 8.5 & 1.2 & 7.5 & 0 & 8.2 & 2.0 \\
\hline
\end{tabular}




\begin{tabular}{|c|c|c|c|c|c|c|c|c|c|c|}
\hline 20 & 4.3 & -0.2 & 5.4 & -0.4 & 6.2 & -2.3 & 7.5 & 0 & 8.3 & 0.1 \\
\hline 21 & 4.3 & 0 & 9.4 & 4.0 & 8.2 & 2.0 & 7.5 & 0 & 6.2 & -2.1 \\
\hline 22 & 2.5 & -1.8 & 5.4 & -4.0 & 7.2 & -1.0 & 7.5 & 0 & 7.3 & 1.1 \\
\hline 23 & 3.5 & 1.0 & 8.8 & 3.4 & 8.3 & 1.1 & 7.5 & 0 & 8.5 & 1.2 \\
\hline 24 & 4.5 & 1.0 & 8.8 & 0 & 7.2 & -1.1 & 7.5 & 0 & 6.2 & -2.3 \\
\hline 25 & 5.2 & 0.7 & 9.3 & 0.5 & 7.2 & 0 & 7.5 & 0 & 8.2 & 2.0 \\
\hline 26 & 5.5 & 0.3 & 10.4 & 1.1 & 6.2 & -1.0 & 7.5 & 0 & 8.3 & 0.1 \\
\hline 27 & 8.2 & 2.7 & 6.4 & -4.0 & 7.3 & 1.1 & 7.5 & 0 & 5.2 & -3.1 \\
\hline 28 & 7.4 & -0.8 & 7.7 & 1.3 & 8.5 & 1.2 & 7.5 & 0 & 7.5 & 2.3 \\
\hline 29 & 6.6 & -0.8 & 8.7 & 1.0 & 6.2 & -2.3 & 7.5 & 0 & 5.9 & -1.6 \\
\hline 30 & 2.5 & -4.1 & 9.4 & 0.7 & 8.2 & 2.0 & 7.5 & 0 & 8.5 & 3.4 \\
\hline & $8.09 *$ & & $7.84^{*}$ & & 7.81* & & $8.75^{*}$ & 0 & 8.95 & \\
\hline
\end{tabular}

Source: Projected and compiled by the Authors

Table 3 as projected and extrapolated by the authors highlighted the trend, movement, mean and variations in the micro-fiscal measures within the thirty years interval covered in the exploration. It explained the state of instability in the micro-fiscal indicators with no point of stability and equilibrium. This implied that the magnitude and quality of real gross national goods and produces which are always determined given the values/quality of these micro-fiscal indicators are also made vulnerable by the high variations and discrepancies in the determinant factors under examination. Consequently, the control and proper management of these determinants and contributing factors will in turn enhance the magnitude and quality of real gross national goods and services.

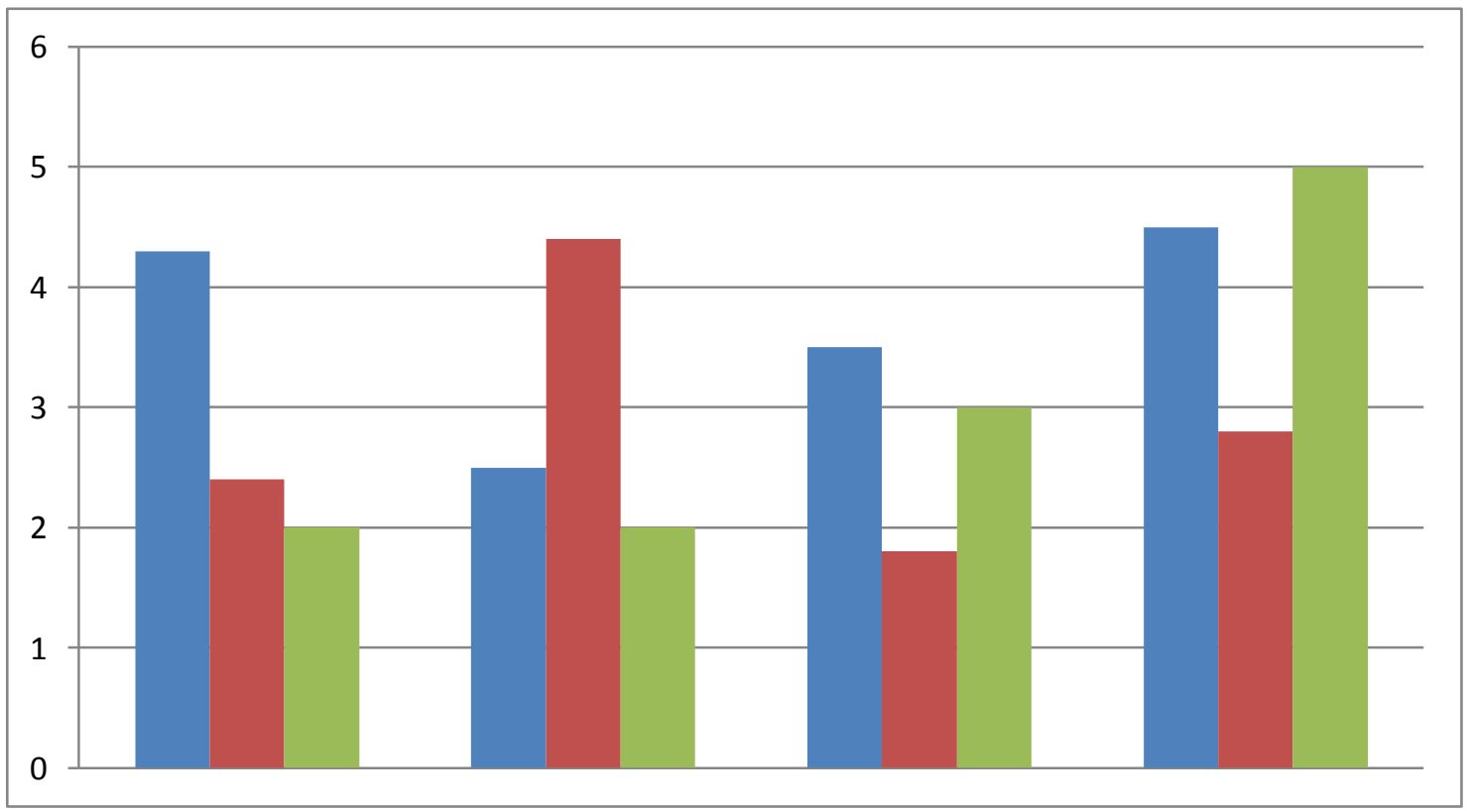

Figure 1. Histogram showing variations and trends to ascertain the quality

Source: Authors' scrutiny and logging of the variations.

This figure is used to illustrate the disorganized changes and haphazard variations in the micro-fiscal indicators; charges ratios, price rises ratios, swap ratios, levy ratios, and purchaser charges catalogues (See Table 3 above), as they influence the quality, values and magnitudes of real gross national goods and services within the thirty years 
(1989-2019) of this exploration. It illuminated the results and breakdowns presented in Tables 1, 2, \& 3 above and a further display in Figure 2 below.

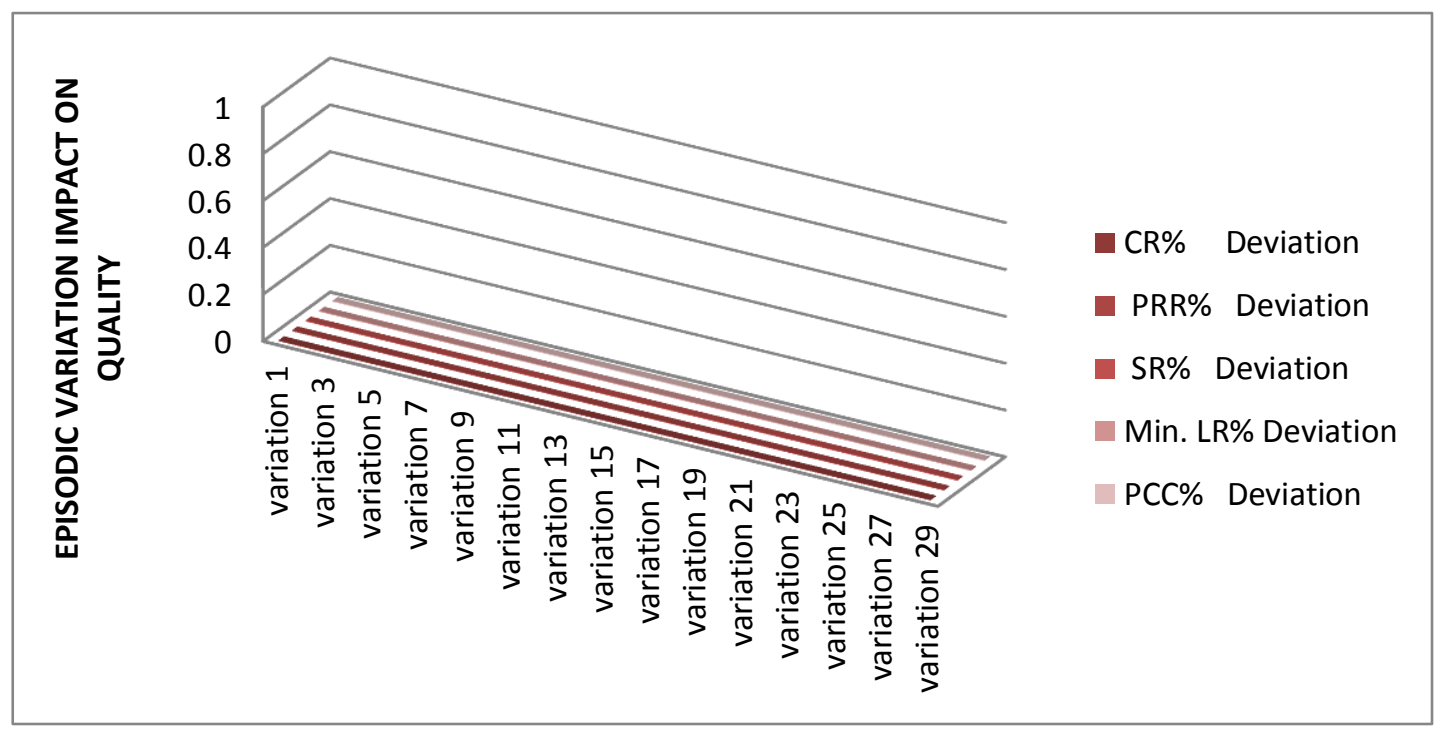

Figure 2. Visual aid indicating variations, trend and quality of micro-fiscal indicators and their influences on the quality and quantity of real gross national goods and services.

Source: Researchers' evaluation and charting of the accounting quality implication of the micro-fiscal measures variation.

Virtual and simulated evaluation of Accounting quality implications of micro-fiscal measures $\{\mathrm{MFM}=\mathrm{CR}, \mathrm{PRR}, \mathrm{SR}$, LR $\}$ on the quality and quantity of real gross national goods and services $\{$ RGNGS $\}$ in real term using time series data. The line chart displays the accounting quality implications or effects of the different types of micro-fiscal measures: Charges ratio, price rises ratio, swap ratio and levy ratio which were categorized into categories $1,2,3$, and 4 respectively in order to ascertain their individual effects on real gross national goods and services, measured in trillions of Naira, for the period of thirty years.

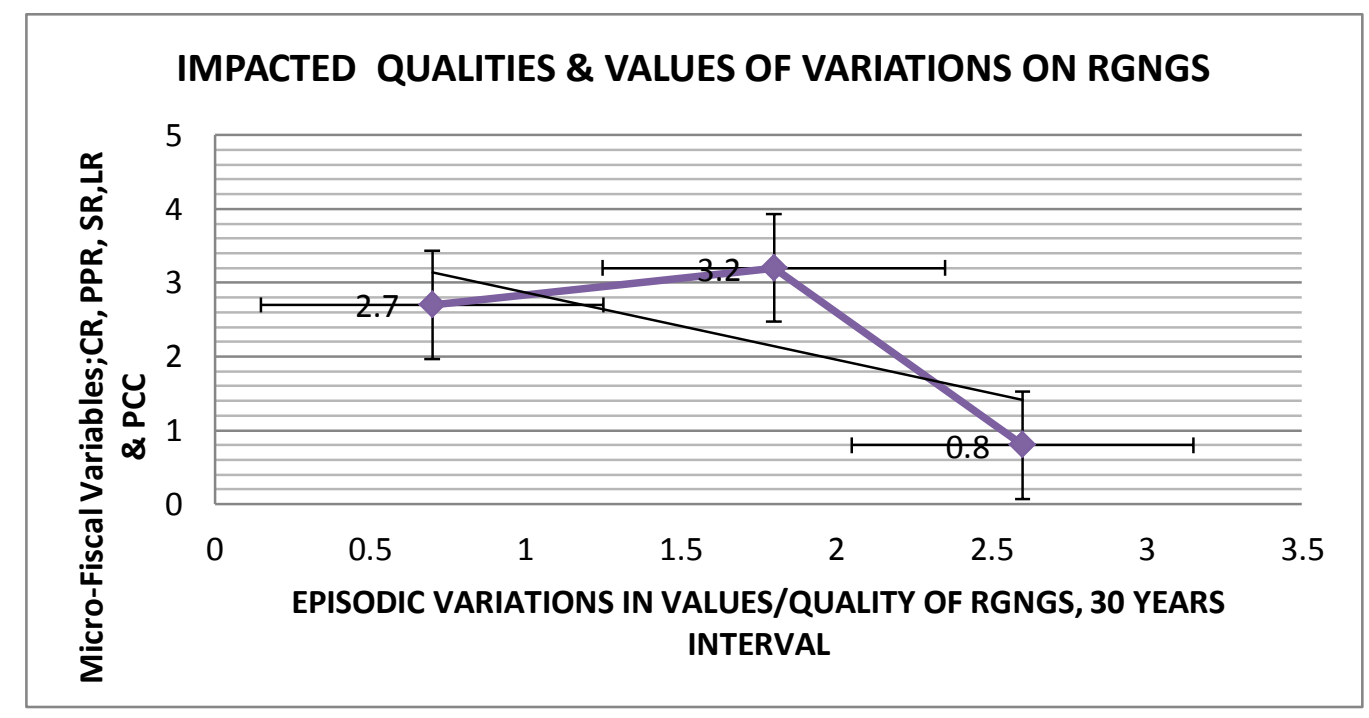

Figure 3. Accounting quality assurance \& implications of values of variations and deviations on the quality of real gross national goods and services 
Figure 3 engendered the full curve and swing extrapolation of variation and changes on the estimated values of real gross national goods and services as caused by the intervallic and episodic trend and inclination of the identified micro-fiscal measures (charges ratios, price rises ratios, swap ratios, levy ratios and purchaser charges catalogues) for the thirty years exploration.

\section{Conclusion}

From the afore findings and discussions, it could be strongly concluded that micro-fiscal measures identified in the study as charges ratio, price rises ratio, the swap ratio could be substantially used to predict the quality and quantity of real gross national goods and services as justified by the empirical evidence from Nigeria. Consequently, the national government in formulating fiscal and monetary policies should pay greater attention to the identified micro-fiscal variables as an economy can be upturned if no consideration is given to the mentioned micro-fiscal variables at any point in time macro-economic policies or goals are contemplated. On the other hand, the nation states which are characterized by rapid upswing and instability in the swap ratio often face with adverse balance of trade. Therefore, proliferation of wealth and asset creation by domestic company as a result of material dwindling in the domestic legal tender could materially reduce formation and creating of real gross national goods and services. However, from non-empirical findings, it was again deduced that sequential cost reports usually quantify interchange prices at the business period and overlook variations in worth, up to one more business taking place. By means of the noteworthy value variations taking place over the previous years, there has been increasing fretfulness around the practicality of historic cost reports and the value of national goods manufactured.

\section{Acknowledgments}

The authors are pleased and enormously thankful to the under-listed persons for their contributions directly and indirectly to the successful completion and preparation of the manuscript of this study: CBN and Nigeria Bureau of Statistics.

\section{References}

Abdulahi, M. A. (2015). The impact of on national income accounting in Nigeria. Advance in Social Science Resource Journal, 4(3), 74-85.

Abdullahi, G. R., Aliero, H. M., \& Abdullahi, M. (2012). Analysis of the relationship productivity and gross domestic products in Nigeria. Multidisciplinary Review of Economy and Management, 3(1), 1-12.

Abraham, A. D. (2019). The role of gross domestic product in economic growth and development to meet the new trend. National staff Training/workshop for vision 2020, unpublished papers.

Adams, E. A. (2001). Public Sector Accounting and Finance Made Simple (2nd ed.). Lagos: Corporate Publishers Ventures, pp. 43-44.

Adejumo, V. A., \& Adejumo, O. O. (2014). Prospects for achieving sustainable development through the millennium development goals in Nigeria. European Journal of Sustainable Development, 3(1), 33-46.

Anyanwu, J. C. (1993). Monetary economics: Theory, policy and institutions. Onitsha: Hybrid Publishers, pp. 65-66.

Anyanwu, J. C. (1995). Modern Macro Economy (2nd ed.). Onitsha: Nigerian Diocesa Press, pp. 50-51.

Asechemie, D. P. S. (1999). Anatomy of Public Sector Accounting in Nigeria (2nd ed.). Port Harcourt: Sunray Books Limited, pp. 197-198.

Asuquo, A. I. (2012a). Accounting for the impact of monetary policy on Nigerian economic growth: Empirical assessment (1981-2010). International Journal of Innovative Research and Development, 1(4), 246-265.

Asuquo, A. I. (2012b). Inflation accounting and control through monetary policy measures in Nigeria: Multi-regression analysis (1973-2010). IOSR Journal of Business and Management, 1(2), 53-62.

Asuquo, A. I., \& Effiong, S. A. (2010). Tax management as an alternative tool for Economic recovery and development in Cross River State. International Journal of Accounting, 1(1), 38-44.

Asuquo, A. I., \& Effiong, S. A. (2011). Empirical analysis of Nigerian fiscal policies and revenue generation processes. Multidisciplinary Journal of Research Development, 17(2), 1-11.

Ayejide, T. (2019). Nigeria Federal finance and prospect. Paper presented in a workshop, Unpublished.

Central Bank of Nigeria [CBN]. (2000). The Changing Structure of the Nigerian Economy and Implications for Lagos: Development. Realm Communications Limited. 
Central Bank of Nigeria [CBN]. (2003). Contemporary Economic Policy Issues in Nigeria. Abuja.

Central Bank of Nigeria [CBN]. (2005). Statistical Bulletin and Reports. Retrieved from http//:www.cbn.gov.ng

Ezeani, O. E. (2004). Local Government Administration (1st ed.). Nigeria: Zik-Chucks, p. 54.

Index Mundi. (2012). Open data. Heritage Foundation Macroeconomic data.

Jhingan, M. L. (2010). Macroeconomic theory (12th ed.). New Delhi: Vrinda Publications Ltd.

Jorion, P. (1990). The pricing of Exchange Rate Risk in Stock Market. Journal and Financial and Quantitative Analysis, 2(2), 363-376.

Luehrman, T. A. (1991). Exchange rate changes and the distribution of industry value. Journal of International Business Studies, 2(8), 25-45.

Okonkwo, S. I. (2015). National Income accounting and economic growth in Nigeria. Journal of Economy and Sustainable Development, 4(1), 1-5.

Udoayang, J. O., Akpanuko, E. E., \& Asuquo, A. I. (2009). Multinational transfer pricing and international taxation: What, why, how and reporting challenges. Africa Research Review: An International Multi-Disciplinary Journal, 3(5), 165-181.

Victor, T. E. (2019). Parameters influencing national productivity in Nigeria. International of Accounting and Business, $3(4), 8-84$.

Vincent. P. O. (2018). Nigeria's macro-economic goals: How achievable. International Journal of Business and Management, 5(6), 146-160.

Wilcox, M. N. (2018). Fiscal policies regimes and developing economies: The Global Alignment. Unpublished seminar paper.

Willey, P. K. (2019). Evaluation of Nigeria's GDP and economic growth. PhD student's unpublished research project.

Williamson, A. P. (2019). Economic tandems in Nigeria. International Journal of Social Sciences, 10(5), 200- 222.

Wilson, E. U. (2019). Accountability for national wealth: The way forward. Retreat and workshop Operational Paper for Senior Public Servants in the Three Tiers of Governments, Unpublished.

Wusen, T. R. (2018). Empirical evaluation of fiscal and monetary policies on Nigerian economic growth. Journal of Accounting Research, Duncan Series, 2(4), 68-88.

Zubeiru, K., \& Adjasi, F. (2007). International competition and exchange rate shocks: A cross-country industry analysis of stock returns. Review of Financial Studies, 14(3), 145-147.

\section{Copyrights}

Copyright for this article is retained by the author(s), with first publication rights granted to the journal.

This is an open-access article distributed under the terms and conditions of the Creative Commons Attribution license (http://creativecommons.org/licenses/by/4.0/). 